\title{
T 2 dentidades Religiosas e Fronteiras ÉTNICAS: UM ESTUDO DO RITUAL DA ORAÇÃO NA COMUNidAdE MUÇUlmana DO RIO DE JANEIRO
}

Gisele Fonseca Chagas

\section{Introdução}

Em "A prece" (1909), Marcel Mauss apresentou a relevância de uma abordagem analítica da prece no campo das Ciências Sociais para o entendimento dos fenômenos religiosos. Em termos metodológicos, a prece aparecia pela primeira vez conectada com outros domínios da vida social dos agentes religiosos, logo, passível de ser analisada não só como uma realidade em si mesma, mas, sobretudo, como uma ação, como um ritual que condensa e manifesta, em termos discursivos e práticos, os valores, as ideias e os sentimentos que formam o corpus das diferentes manifestações religiosas.

Cem anos depois, percebe-se ainda a atualidade das questões levantadas por Mauss em seu texto, uma vez que, no cenário contemporâneo, as múltiplas formas pelas quais as religiões estão inseridas na esfera pública permitiram que as diferentes tradições religiosas se tornassem veículos de mobilização cultural, social e política para diferentes agentes sociais. Nesse sentido, uma análise antropológica dos fenômenos religiosos deve levar em conta não só os contextos nos quais eles são vivenciados, mas também os diferentes meios pelos quais são produzidos e apropriados, ritual e discursivamente, como parte das identidades religiosas reivindicadas. 
De acordo com o autor, a prece é um fenômeno social porque as formas que assume têm origem exclusivamente social, a partir dos rituais que são consagrados pelas tradições religiosas e praticados por seus fiéis; e a sua natureza oral - expressa pela palavra - comunica o seu conteúdo. Embora a utilização da palavra permita uma maior mobilidade aos agentes religiosos na comunicação com o sagrado, Mauss indica que tal comunicação é feita num quadro limitado de referências morais e de usos de uma linguagem apropriada, cujo vocabulário, seja no caso da prece individual ou coletiva, é dado pelas tradições religiosas, tendo por referência os seus textos normativos: o "livro sagrado" de cada uma delas. (Mauss [1909] 1979:116-122).

Partindo dessas reflexões iniciais de Mauss, o objetivo deste $\operatorname{artigo}^{1}$ é discutir o papel da prece no processo de construção das identidades religiosas da comunidade muçulmana sunita do Rio de Janeiro, tendo como foco os diferentes efeitos sociais que essa prática produz entre seus membros. Para tanto, as conexões entre as formas de codificação e o conhecimento religioso e as relações de poder daí resultantes se tornam fundamentais para a análise aqui proposta, uma vez que o Islã sunita, como o praticado pela comunidade do Rio de Janeiro, está codificado discursivamente em textos normativos que informam suas práticas rituais - tais como a oração coletiva de sexta-feira, ritual em que coletei os dados etnográficos que serão apresentados ao longo deste trabalho.

Tradições religiosas transnacionais como a islâmica ${ }^{2}$ podem ser entendidas como tradições de conhecimento do sagrado que orientam a forma de "ser" e de "agir" dos agentes religiosos, sendo, então, marcadas por uma diversidade de ideias e práticas religiosas contextualmente produzidas e transmitidas de diferentes maneiras. Nesse aspecto, a análise de Harvey Whitehouse (2000) sobre os dois modos divergentes de religiosidade (doutrinal e imagístico), classificados a partir de diferentes processos de codificação e transmissão de conhecimento religioso, se torna significativa para a presente discussão.

A abordagem de Whitehouse pontua a relevância da memória para as teorias sociais, argumentando que, para o entendimento das formas pelas quais as pessoas se sentem compartilhando uma identidade comum, é preciso que se leve em consideração os mecanismos de ativação da memória humana que são utilizados (Whitehouse 2000:4-12).

O ponto de partida para o seu modelo dos dois modos de religiosidade divergentes (doutrinal e imagístico) tem por base a dicotomia entre a memória semântica (representações mentais de uma natureza geral, criadas pela repetição dos aspectos rituais) e a memória episódica (representações mentais de eventos experimentados pessoalmente, conceitualizados como episódios únicos na vida de uma pessoa) que, acionadas de diferentes maneiras, geram, respectivamente, o modo doutrinal e o modo imagístico.

No modo doutrinal proposto pelo autor em tela, as ideias religiosas são 
codificadas discursivamente em um corpus de doutrinas que aspiram coerência interna e que são as bases para as atividades rituais como, por exemplo, as orações e os sermões. No entanto, tradições religiosas doutrinais, para serem efetivas e duradouras, precisam criar meios para controlar e estabilizar o conteúdo das revelações religiosas que estão codificadas nos textos sagrados. Para o autor, a eficácia do modo doutrinal na disseminação do discurso religioso está em sua forma rotinizada de transmissão do conhecimento relativo à religião (Whitehouse 2000:9).

A organização e a transmissão das ideias que fundamentam as religiões que operam no modo doutrinal só foram possíveis com o surgimento da escrita. Jack Goody (1988) ressaltou que a introdução da escrita ocasionou transformações nos modos de transmissão do conhecimento, alterando também o seu conteúdo. A escrita tornou o conhecimento universalizável, pois permitiu que ele, uma vez codificado discursivamente em textos, se tornasse mais abstrato, descontextualizado e impessoal, sujeito a críticas, comentários e reordenamentos, estimulando, então, a elaboração da ortodoxia e suas regras de procedimento (Goody 1987:47, 54-55, 88, 98-101). Nessa linha, seguindo as contribuições de Roger Chartier (1998), sublinho também a importância das práticas de leitura e da recepção dos textos religiosos que compõem a tradição, não só no que diz respeito à divulgação de seu teor, mas também tendo em vista os diferentes efeitos que esse procedimento tem nas identidades religiosas dos agentes sociais, tal como procurarei explorar mais à frente.

O conhecimento religioso codificado discursivamente em textos, ao descontextualizar os conceitos religiosos e despersonalizar sua revelação, permitiu que essa fosse difundida, formando amplas comunidades anônimas (Whitehouse 2000:1). Desse modo, foi no âmbito das religiões mundiais organizadas a partir do emprego de técnicas da escrita que surgiram os profetas como anunciadores de uma nova ordem moral (ou uma reordenação da moral já existente), codificada em textos doutrinais e práticas rituais elaboradas para serem divulgadas, daí a existência de atividades missionárias que objetivam a conversão (Goody 1987:2021) - entendida neste artigo como a aceitação intelectual e emocional de um conjunto de crenças e práticas percebidas como corretas.

Por outro lado, segundo Harvey Whitehouse, o modo imagístico pode ser entendido como uma forma de codificação religiosa centrada em ritos traumáticos, esporádicos e sigilosos, que despertam sentimentos muito fortes e levam os participantes a se unirem através de laços de intensa solidariedade. $O$ modo imagístico de codificação religiosa é restrito a pequenos grupos, não podendo alcançar comunidades mais amplas, uma vez que é uma codificação não verbal, que dispensa mediações, em que cada indivíduo só vivencia uma vez a experiência com caráter revelatório, não tendo como expressá-la, monitorá-la ou controlar sua transmissão. 
Mais importante que o modelo proposto por Whitehouse, uma vez que nem sempre os limites entre as codificações doutrinais e imagísticas podem ser rigidamente estabelecidos ${ }^{3}$, são as questões levantadas por ele com relação às formas de transmissão do conhecimento religioso e aos mecanismos disciplinares que são utilizados para fazer com que a mensagem/revelação permaneça entre os seus adeptos, que a atualizam mantendo-se unidos em nome do compartilhamento comum das verdades religiosas.

Nesse aspecto, a análise de Fredrik Barth (2000) sobre os modos de transação do conhecimento permite a elucidação das maneiras pelas quais as tradições religiosas são transformadas em realidades sociais. Para ele, cada sociedade está permeada por diferentes tradições de conhecimento que informam a vida social e, para apreendê-las, é preciso investigar as maneiras pelas quais o conhecimento é transmitido e gerenciado na interação social. (Barth 2000:144).

Barth propõe, para tanto, dois modelos contrastantes de transmissão de conhecimento nos papéis de "guru" e de "iniciador". Esses papéis divergentes, acionando diferentes modalidades de conhecimento, implicam "transformações cumulativas" na própria tradição que é transmitida.

A transmissão de conhecimento desempenhada pelo iniciador é contextualizável, ocorrendo somente nas ações rituais. É ele quem domina o conhecimento da religião e os procedimentos de manipulação dos símbolos sagrados, tendo o poder de invocá-los. Sua autoridade é legitimada por sua performance ritual e pela capacidade que tem de proporcionar experiências emocionantes e intensas aos iniciantes, a ponto de fazer com que eles se sintam transformados pela própria ação ritual. $O$ conhecimento do iniciador não é sistematizado em ideias que aspiram coerência; ao contrário, é obtido através de sua transação com ancestrais ou forças da natureza, por isso a ênfase ao mistério que envolve a revelação ritual e o segredo no seu contato com o sagrado.

Por outro lado, o papel do guru é marcado por um processo de gradual acúmulo de conhecimento. Sua legitimidade é alcançada através da transmissão pública desse conhecimento, que deve ser percebido como coerente e satisfatório por seu público, com o qual mantém uma relação "professoral", pedagógica. Nas palavras de Barth:

A tarefa do guru no relacionamento com o seu público é instruir, esclarecer e educar, de modo que seus discípulos aprendam com ele em uma relação pessoal e duradoura. [...] Por isso, antes de mais nada, é fundamental não ficar sem ter o que transmitir: um guru só se sustenta enquanto tem o que ensinar. [...] Se um guru entra em contradição, ou se seu estoque de conhecimento se exaure, ele é rapidamente ofuscado pelos seus rivais ou discípulos (Barth 2000:147). 
Apesar de o Islã não possuir uma organização institucionalizada de sacerdotes, tal como ocorre no cristianismo, sua estruturação em torno de uma revelação codificada discursivamente em textos sagrados atribui às autoridades religiosas papéis de guardiãs da tradição, sendo elas as responsáveis pela permanente transmissão dos ideais formativos da religião. Dessa forma, o conhecimento religioso publicamente demonstrado é fundamental para a consagração e a manutenção do status de uma liderança religiosa.

Religiões codificadas doutrinalmente, como o Islã sunita praticado na comunidade do Rio de Janeiro, adotam formas rotinizadas e públicas de transmissão de seus valores. A repetição dos aspectos rituais que fazem parte das religiões doutrinais desempenha, por si mesma, funções disciplinares, uma vez que possibilita a memorização dos esquemas gerais do conhecimento religioso por seus adeptos e permite que eles aprendam exatamente como proceder durante os rituais, além de serem capazes de descrevê-los e de verbalizar suas experiências em qualquer contexto.

Nessa linha, Talal Asad (1986), ao considerar o Islã uma tradição discursiva que "[...] consiste essencialmente de discursos que procuram instruir especialistas com respeito às formas e propósitos corretos de uma dada prática que, precisamente porque está estabelecida, tem uma história” (Asad 1986:14), evidencia o papel da ortodoxia nos processos de ensino doutrinal e ritual da religião.

Mais do que discursos instrutivos sobre as práticas religiosas, a ortodoxia é estruturada a partir de relações de poder que legitimam a força normativa da tradição religiosa através da aplicação de práticas disciplinares, definidas como "os múltiplos caminhos nos quais discursos religiosos regulam, informam e constroem o 'self' dos agentes religiosos" (Asad 1993:125). Assim, a noção de ortodoxia demanda especialistas no texto, que criam interpretações canônicas e têm seu conhecimento religioso legitimado publicamente como autoridade.

As práticas disciplinares aplicadas pelas tradições religiosas são capazes de construir, moldar e dirigir as condutas dos seus adeptos através de mecanismos (regras e punições) que induzem o seu "estar no mundo", isto é, suas disposições espirituais, morais e físicas, permitindo a construção de um habitus ${ }^{4}$ religioso a partir da internalização dos valores religiosos normativos. No entanto, as formas pelas quais as práticas disciplinares são aplicadas e organizadas pedagogicamente por tais especialistas não são homogêneas e variam, tanto de acordo com os veículos pelos quais a tradição religiosa é codificada e transmitida, quanto com relação à sua recepção pelos agentes religiosos.

Com base nas articulações teóricas esboçadas acima, que podem ser conectadas à discussão inicial de Marcel Mauss sobre a prece, analisarei o ritual da oração coletiva de sexta-feira (obrigatória para os homens muçulmanos) praticada na comunidade sunita em questão, no intuito de apreender os processos 
dinâmicos pelos quais as identidades religiosas dos seus praticantes são construídas e delimitadas. Essas articulações se apresentam fundamentais para este trabalho, uma vez que o Islã, como um sistema religioso baseado em uma revelação profética codificada discursivamente em texto, se articula em torno da transmissão do conhecimento religioso.

\section{A comunidade sunita do Rio de Janeiro}

O Islã ocupa uma posição minoritária no campo religioso brasileiro, cujo universo discursivo e prático é marcado predominantemente pelo cristianismo. Embora a presença histórica de muçulmanos remonte ao período da escravidão, em que muitos cativos eram trazidos de áreas africanas islamizadas (Reis 2003), o processo de formação e organização institucional das comunidades muçulmanas no Brasil somente pode ser identificado em diferentes momentos do século XX, a partir de fluxos migratórios árabes, sobretudo de sírios, libaneses e, mais recentemente, palestinos. Estima-se que seis milhões de árabes e seus descendentes vivam hoje no Brasil e, desses, um milhão são muçulmanos (Pinto 2005a).

Uma análise de tradições religiosas universais codificadas em textos sagrados e práticas rituais como o Islã deve levar em consideração as diferentes maneiras pelas quais seu conteúdo é apropriado, ressignificado e vivenciado no cotidiano pelos diversos agentes religiosos. Nessa linha, a produção antropológica sobre as comunidades muçulmanas no Brasil aponta para a pluralidade de formas nas quais elementos sociológicos tais como etnia, nacionalidade, gênero, conversão etc. são articulados de acordo com diferentes contextos, além de indicarem os meios pelos quais esses grupos diaspóricos se conectam ao imaginário religioso islâmico localizado no Oriente Médio (Ferreira 2007; Chagas 2006; Pinto 2005a; Montenegro 2000).

De maneira geral, as comunidades muçulmanas no Brasil são urbanas e reproduzem o quadro mais amplo das diferenças sectárias, tendo mais muçulmanos e instituições religiosas sunitas do que xiitas. Com relação aos xiitas, a maior parte desse grupo está localizada em São Paulo e na região sul, mais especificamente em Curitiba e em Foz do Iguaçu. Já as comunidades muçulmanas sunitas estão localizadas em uma área mais ampla do território nacional, sendo os estados de São Paulo, Paraná, Rio Grande do Sul, Rio de Janeiro e o Distrito Federal os de maior concentração de fiéis.

A população sunita do Rio de Janeiro, objeto deste artigo, apresenta uma composição sociológica peculiar em relação às demais. Embora tenha sido criada em 1951, a Sociedade Beneficente Muçulmana do Rio de Janeiro (SBMRJ) instituição que reúne a comunidade, situada no centro da cidade ${ }^{5}$ - recebeu um impulso em sua organização somente na década de 1990, quando um pequeno 
grupo de muçulmanos (de origem árabe) resolveu levar adiante o projeto de fazer da SBMRJ tanto um espaço de congregação para os nascidos muçulmanos (aqueles que tem a religião como herança cultural), quanto um instrumento para a divulgação do Islã no Rio de Janeiro. Segundo os líderes da comunidade, existem cerca de 5 mil muçulmanos no Estado. Embora o número de filiados a SBMRJ seja restrito ${ }^{6}$, o alcance simbólico que ela adquiriu como foco da vida religiosa, ritual e social dos muçulmanos sunitas do Rio de Janeiro é significativo, pois é através das atividades que acontecem em seu âmbito que os muçulmanos se concretizam como comunidade religiosa.

O perfil social dos membros da comunidade muçulmana do Rio de Janeiro é muito diversificado: classe média/baixa, englobando, em linhas gerais, profissionais liberais, comerciantes, estudantes universitários, donas de casa, vendedores ambulantes etc. Alguns dos comerciantes que frequentam a SBMRJ também possuem formação universitária.

Diferentemente da composição das outras comunidades do Brasil, formadas majoritariamente por árabes e seus descendentes, que acabam por associar a identidade étnica (árabe) à identidade religiosa (muçulmana), se caracterizando, então, por um maior contato com o Islã praticado no Oriente Médio, a comunidade do Rio de Janeiro singulariza-se por ser de formação mais recente e ter a maioria dos seus membros composta de brasileiros, sem ascendência árabe e convertidos?

O caráter multiétnico dessa comunidade (árabes e descendentes, brasileiros convertidos e africanos ${ }^{8}$ ) faz com que grande parte das atividades promovidas pela SBMRJ seja voltada para a socialização/instrução dos seus membros em geral e, mais particularmente, dos brasileiros convertidos na doutrina e práticas islâmicas, além de focar também a divulgação do Islã, objetivando sua maior inserção no campo religioso local. Essa inserção ocorre de diversas maneiras: através da promoção de atividades beneficentes, participações em eventos como palestras, organização de cursos sobre temáticas que envolvam o Islã, encontros ecumênicos etc., que marcam o caráter missionário, mas não proselitista, desse grupo.

As atividades desenvolvidas na SBMRJ que contam com a participação dos membros da comunidade compreendem as orações obrigatórias de sextafeira (salat al-jumaat ${ }^{9}$ ) -ocasião na qual são proferidos os sermões (Khutba) -, os cursos de introdução ao Islã e língua árabe, além de festividades rituais estabelecidas pelo calendário islâmico.

\section{Conhecimento religioso e relações de poder: a oração ritual de sexta-feira}

Um aspecto central que perpassa todos os discursos dos membros da comunidade muçulmana do Rio de Janeiro, como um importante elemento constitutivo da doutrina islâmica, é o do conhecimento. "Um muçulmano deve 
buscar conhecimento até na China" - esse dito atribuído ao Profeta Muhammad ${ }^{10}$ era constantemente citado por meus informantes sempre que eu os perguntava sobre o Islã e as práticas dos muçulmanos.

A procura por saber, especialmente o religioso, é uma obrigação de todo muçulmano e, para os membros da SBMRJ, essa obrigação deve ser cumprida através da leitura dos textos religiosos, principalmente o Alcorão e as hadiths, e da participação nas atividades comunitárias realizadas na instituição.

Essa referência ao conhecimento passa pela apreensão intelectual da doutrina e, por conseguinte, pelo acesso ao texto corânico original, escrito em árabe, que é regularmente relatado pelos muçulmanos não falantes do idioma que frequentam a SBMRJ como uma meta a ser alcançada a longo prazo, através de estudo e dedicação. Para os muçulmanos, o Alcorão é o livro sagrado por conter as palavras de Deus, imutáveis, exatamente na formulação em que foram reveladas ao profeta - por isso, a ideia da autenticidade do texto em árabe levanta problemas para sua tradução para outros idiomas. Ler o Corão em árabe, língua original da revelação divina, é não só uma forma recomendada para obtenção do conhecimento religioso, mas também um caminho para a própria "salvação" do crente. A língua árabe, desse modo, é uma chave simbólica tanto para a apreensão das palavras de Deus quanto para fornecer aos muçulmanos uma linguagem religiosa universal, um elemento fixo e agregador no que diz respeito ao pertencimento à comunidade universal de fiéis (ummah).

Desse modo, nos discursos dos membros da SBMRJ, os muçulmanos que detêm o domínio linguístico do árabe, notadamente árabes ou descendentes já nascidos na religião, são classificados como aqueles que estão mais "próximos" do saber religioso, por conta da facilidade que encontram para ler o Alcorão em "sua língua original", fator que contribui para delinear uma suave fronteira étnica que se estabelece entre os membros da comunidade nos processos de aquisição e de demonstração pública de conhecimento religioso.

Camila ${ }^{11}$, uma muçulmana brasileira de 27 anos, convertida há três, e que domina razoavelmente o árabe por ter estudado, em suas palavras, "a sério o idioma”, chegando, inclusive, a alfabetizar em língua árabe na instituição para a turma que frequentei, me disse em uma conversa informal que "todos os muçulmanos devem se empenhar para aprender a língua, para saber o que estão memorizando, para fazer as orações e também para ler o Alcorão, mas que isso quase ninguém da comunidade faz".

$\mathrm{Na}$ mesma conversa, falei da diversidade étnica na comunidade e da constatação de que havia mais brasileiros como membros da SBMRJ e que poucos desses tinham algum conhecimento da língua árabe; ela me respondeu que na comunidade, além dos brasileiros, os africanos também são maioria em relação aos árabes, mas que no tocante ao conhecimento religioso, os árabes possuíam mais que os outros, por conta do domínio cultural do idioma, "sendo 
os mais indicados para lecionarem os cursos de divulgação do Islã, uma vez que podem ler e entender o Alcorão na língua da revelação e que isso facilita o acesso aos textos para aqueles que não dominam o idioma".

As afirmações acima indicam que o domínio da língua árabe e a expressão pública dessa habilidade fazem parte do capital simbólico - definido por Pierre Bourdieu (1997:178-180) como a acumulação simbólica de bens como educação ou talento artístico, que são transformados em poder e prestígio social - que assegura aos falantes do idioma uma posição de destaque no campo religioso em que a comunidade local está inserida.

No entanto, como acontece em qualquer campo, que Bourdieu (2001:6473) define como o espaço de disputas entre os agentes nele posicionados, o campo religioso da SBMRJ é marcado por disputas em torno da valorização e da consagração do saber religioso. Isso se torna perceptível nos discursos de alguns muçulmanos convertidos com os quais tive contato em diferentes circunstâncias na SBMRJ, para quem as lideranças da instituição, notadamente o Imam Omar ${ }^{12}$ (autoridade religiosa local) e os membros do departamento educacional, todos hábeis na língua árabe, são efetivamente tidos como referências na questão do conhecimento doutrinal da religião; embora nem todos os nascidos muçulmanos falantes do árabe que frequentam a SBMRJ ocupem, de fato, a mesma posição na classificação dos convertidos.

Dito de outro modo: nos discursos dos convertidos aparecem críticas às condutas religiosas de alguns árabes (ou descendentes) nascidos muçulmanos, que embora tenham, na maioria das vezes, domínio do árabe, "não procuram praticar corretamente a religião e a ler o Alcorão", como me disse Lúcia, uma brasileira de 31 anos, convertida ao Islã há três, comerciante e casada com um muçulmano também convertido, cuja família é árabe de origem libanesa e cristã.

Daniela, outra muçulmana convertida, me disse informalmente após uma oração de sexta-feira que

nem todos muçulmanos procuram ter conhecimento da religião. Tenho alguns amigos árabes nascidos muçulmanos que vivem em países majoritariamente muçulmanos que elogiam minha conversão, ainda mais por eu ser brasileira, isso porque eles têm uma ideia do Brasil como carnaval o tempo inteiro, e dizem que conheço muito mais alguns princípios da religião do que eles próprios.

Lúcia, em uma conversa comigo sobre o fato de ser muçulmana no Brasil, direcionou o assunto para o saber religioso. Ela me disse que trabalha em uma loja comercial no SAARA e que seus patróes, libaneses nascidos muçulmanos, "fazem as práticas da religião sem, muitas vezes, saber por que fazem, diferente dos convertidos, que sempre procuram saber e explicar tudo o que fazem na 
religião, porque no Islã tudo tem uma razão e as coisas se encaixam bem". Como exemplo, ela contou que

uma vez, no trabalho, um cliente entrou na loja com um cachorro e eu peguei o animal no colo; daí um dos meus patrões me disse que eu não poderia segurar o cachorro, pois eu iria fazer a oração da tarde. Então, perguntei a ele por que eu não poderia e ele não soube responder. Perguntei só para saber se ele sabia a resposta, pois eu já sabia.

Nos exemplos dados acima, percebe-se o empenho das muçulmanas convertidas em dar coerência às novas práticas religiosas que foram incorporadas ao seu cotidiano através da criação de um habitus religioso, afirmando e legitimando, assim, suas identidades religiosas a partir do conhecimento doutrinal da religião. As convertidas apresentam esse conhecimento como resultado de um empenho pessoal e intelectual, mais do que de um simples consenso cultural, como no caso dos nascidos muçulmanos. A instrução religiosa, nesse caso, funciona como um medidor de religiosidade que é trazido para o debate sempre que os convertidos da SBMRJ precisam marcar suas posições no interior da comunidade.

O conhecimento é percebido como um longo processo de aprendizado que envolve a leitura dos textos sagrados e a articulação dos princípios morais e práticos neles contidos com os costumes cotidianos dos muçulmanos. Então, na arena de disputas internas estruturadas a partir do saber religioso acumulado de maneira individualizada pelos membros da comunidade, os árabes nascidos muçulmanos são percebidos em vantagem - ao menos em termos simbólicos com relação aos muçulmanos convertidos, por já vivenciarem a religião desde que nasceram. A fala de Sumaia, 19 anos, estudante do ensino médio, nascida muçulmana nos Emirados Árabes, tendo vindo para o Brasil com a família aos quatro anos de idade, evidencia o conflito envolvendo convertidos e nascidos muçulmanos com relação ao conhecimento religioso na SBMRJ:

$\mathrm{Na}$ religião não existe diferenciação entre os muçulmanos, o maior exemplo é o hajj, em que as pessoas rezam todas juntas; independente se são convertidas ou não, ricas ou pobres, estão todas juntas. [A diferenciação] ocorre pela burrice do ser humano, de um muçulmano que nasceu na religião achar que, pelos seus pais serem muçulmanos, tem um conhecimento maior do que os convertidos. Na minha opinião, um convertido se empenha bem mais pela religião, porque precisa mudar todos os seus princípios para adotar os do Islã. A religião é perfeita, as pessoas não. 
A fala crítica de Sumaia, que não domina fluentemente o árabe, pode ser contrastada com a de Nizar, também nascido muçulmano e com ascendência árabe, que em conversa comigo sobre ser muçulmano no Brasil, disse que "o Islã é um processo de aprendizado diário, e isso mexe com a pessoa que entra na religião. O convertido se cobra muito, acha que deve ser um modelo de muçulmano de uma hora para outra e isso não é bem assim". Esses nascidos muçulmanos ocupam posições de poder diferenciadas na SBMRJ e têm acessos diferentes ao conhecimento, uma vez que Nizar, por exemplo, tem domínio da língua árabe e internamente é considerado um dos membros da comunidade que mais possui instrução religiosa, fato que faz com que suas visões a respeito dos muçulmanos convertidos sejam diferentes.

Como assinalou Talal Asad (1986:14), contudo, o Islã, como uma tradição discursiva, não pode ser livremente interpretado, pois a manutenção da ortodoxia supõe relações de poder que sustentem o papel das autoridades religiosas em interpretar os textos sagrados e transmiti-los para os fiéis. Desse modo, o processo de aprendizado do Islã não envolve apenas o engajamento individual do muçulmano, mas também a mediação daqueles que são autorizados pela tradição religiosa a falar por ela.

Imam Omar, falando sobre o Islã, disse aos muçulmanos presentes na SBMRJ em uma sexta-feira que "o conhecimento deve ser passado de acordo com a capacidade de assimilação das pessoas". Essa fala deixa claro que embora a procura por conhecimento religioso seja obrigatória para todos muçulmanos, tal conhecimento não está disponível a todos da mesma maneira e sua distribuição deve ser orientada, mediada e controlada por aqueles que demonstram ter o maior acúmulo de conhecimento.

Assim, tratarei da oração de sexta-feira como uma das diversas fontes de saber religioso que existem e circulam na SBMRJ, analisando como esse saber é disponibilizado e mediado pelas autoridades religiosas locais, e apropriado como parte das identidades religiosas dos muçulmanos.

A maioria dos membros da comunidade muçulmana do Rio de Janeiro tem acesso ao conhecimento religioso frequentando as atividades que ocorrem na SBMRJ. A instituição, nesse sentido, ocupa um lugar privilegiado no imaginário religioso de seus membros, agindo como um centro de oração e de congregação da comunidade, onde há o compartilhamento de crenças e práticas religiosas.

Foi no âmbito das atividades comunitárias que ocorrem na SBMRJ que as relações de poder que estruturam internamente a comunidade e a autoridade religiosa exercida pelo Imam puderam ser percebidas mais claramente por mim durante a pesquisa, principalmente nas orações que acontecem às sextas-feiras.

As orações rituais, como um dos pilares do Islã, são organizadas de acordo com regras previamente estabelecidas no Alcorão e na Sunna e devem ser praticadas por todos os muçulmanos que já tenham atingido a puberdade. De 
acordo com a doutrina islâmica, para a realização das orações e para que elas tenham validade e sejam aceitas por Deus, é preciso que os muçulmanos pratiquem-nas de acordo com as recomendações deixadas pelo Profeta. Tais recomendações referem-se principalmente à higienização do corpo (banho e ablução) e das roupas dos muçulmanos, bem como à do local de oração, que devem estar livres de impurezas como fezes, urina, sêmen, saliva de cachorro, sangue e álcool. Também é recomendado que o muçulmano observe corretamente os horários das cinco orações diárias e que as realize direcionado a Meca.

No caso do Islã, a oração (salat) é uma das mais importantes obrigações religiosas do muçulmano e, uma vez que é preciso realizá-la cinco vezes ao longo do dia, marca o ritmo da vida cotidiana do praticante não só no momento ritual da oração em si mesma, mas também nos momentos de preparação que a antecedem (higiene corporal e do lugar no qual ela será feita). A literatura antropológica contemporânea que trata de questões envolvendo o papel da salat tem apontado para os diferentes efeitos sociais que sua prática tem assumido em contextos majoritariamente muçulmanos. Tais trabalhos (Mahmood 2005; Henkel 2005; Deeb 2006), além de ressaltarem os aspectos necessariamente religiosos da salat, destacando que através dela há a renovação do compromisso do fiel com a tradição islâmica, também indicam diferentes projetos de pertencimento ao Islã, sejam eles políticos, religiosos ou culturais, que são mobilizados através da sua performance diária e pública; elementos que conferem ao ritual em tela uma ampla gama de significados e de capital social contextualmente produzidos.

Todas as cinco orações diárias são obrigatórias, tendo mais méritos se forem realizadas comunitariamente nas mesquitas, embora os muçulmanos possam fazê-las em qualquer lugar, como nos locais de trabalho ou em suas casas. Contudo, a oração de sexta-feira (salat al-jumaat), que é acompanhada de sermão (khutba), deve ser realizada obrigatoriamente na mesquita, sendo que essa obrigação é somente para os homens.

A oração de sexta-feira é a atividade que mais reúne os membros da comunidade muçulmana do Rio de Janeiro na SBMRJ: em média, a frequência era de 70 a 90 pessoas, embora houvesse dias em que a mesquita recebia um maior número de participantes e, quando isso acontecia, por razões de espaço, as orações eram realizadas em dois turnos. Pela obrigatoriedade religiosa, a maioria dos frequentadores era de homens, embora algumas mulheres muçulmanas também costumassem participar. No pequeno grupo das mulheres que compareciam às orações de sexta-feira na mesquita, que não ultrapassava a média de 15 devotas, a maioria é de muçulmanas convertidas. Essas, por serem majoritariamente solteiras, costumam ir sozinhas para a mesquita. Já as muçulmanas casadas, em geral, vão acompanhadas por seus maridos, filhos ou parentes.

Alguns homens muçulmanos convertidos costumavam levar suas esposas (não muçulmanas) para assistirem às orações e aos sermões na mesquita. Quando 
isso acontecia, eles faziam o papel de divulgadores do Islã, uma vez que traziam suas esposas para "conhecerem" o Islã na própria mesquita, reforçando o papel dessa no imaginário religioso dos muçulmanos como lugar especial para a prática religiosa. As esposas geralmente pertencem a outras denominações que compõem o campo religioso brasileiro, sendo católicas ou evangélicas, por exemplo.

Certa vez, a esposa de um brasileiro muçulmano convertido há dois anos sentou-se ao meu lado na mesquita, perto da porta de entrada. Quando o relógio de parede, que fica perto da porta, emitiu a chamada da oração, em tom baixo, uma vez que só quem está sentado próximo a ele pode ouvir, ela se mostrou surpresa. Então expliquei a ela que o som estava sendo emitido pelo relógio e que indicava que estava na hora da oração começar. A mulher, então, perguntou se eu era muçulmana. Respondi que não, que eu sou pesquisadora e que estava ali para "conhecer o Islã". Ela me revelou ser evangélica da Igreja Nova Vida e disse que seu marido também era, mas que se desentendeu com o pastor e "resolveu mudar de religião e se tornar muçulmano". Perguntei se ela também se tornaria muçulmana, ao que respondeu que não, que só estava na SBMRJ naquela sexta-feira por causa do marido, que insistia há muito tempo para que ela fosse até lá, porque, para ela, o "Islã é uma religião muito diferente". Essa situação indica que os muçulmanos do Rio de Janeiro, principalmente os convertidos, têm relações pessoais muito estreitas com seguidores de outras tradições religiosas e, nesse caso, o marido tentava aproximar a esposa dos valores e códigos islâmicos, aos quais ela estava relutante por considerá-los "diferentes" cultural e religiosamente das referências cristãs com as quais ela estava ambientada.

Como o espaço físico da SBMRJ é pequeno, não há um lugar específico para orações destinado às mulheres, como acontece em algumas outras instituições muçulmanas no Brasil, como as de São Paulo, por exemplo. No entanto, há uma pequena parte da sala que lhes fica simbolicamente reservada, uma vez que, como regra religiosa, a mulher deve ficar atrás do homem nas orações.

Os visitantes externos (pesquisadores, estudantes, jornalistas e curiosos) não muçulmanos que frequentemente assistem ao ritual da oração na mesquita se acomodam em cadeiras que são arrumadas em três pequenas fileiras perto da porta de entrada, onde fica a área administrativa. Tais cadeiras também costumam ser utilizadas pelos muçulmanos mais idosos que, por limitações físicas, não conseguem prostrarem-se nos momentos da oração. A visão do ritual a partir das cadeiras é ampla, uma vez que elas ficam posicionadas na direção do púlpito em que o Imam profere os sermões, permitindo, também, uma visão geral dos membros da comunidade.

Todos os que participam do ritual devem observar algumas regras de vestimenta: para os homens, calças ou bermudas cujo comprimento ultrapasse o 
joelho; já as mulheres muçulmanas devem deixar à mostra apenas rosto, pés e mãos. Com relação aos visitantes externos que não conhecem os códigos islâmicos para vestimentas, principalmente no caso das mulheres que, às vezes, chegam à SBMRJ com roupas consideradas impróprias para o local, a secretária da instituição, gentilmente, se dirige a eles e lhes pede para que se vistam de acordo com as regras locais, emprestando às mulheres saias compridas, que muitas vezes podem servir também para cobrir o colo e os ombros, como uma espécie de xale.

Como estratégia de campo, passei a chegar mais cedo na mesquita às sextas-feiras, com o objetivo de conseguir me inserir mais na comunidade e estabelecer contatos com os membros que eu só encontrava naquela ocasião. A oração começava ao meio-dia e, passando a chegar com mais de uma hora de antecedência na mesquita, pude perceber que muitos membros da comunidade também chegavam mais cedo, tanto para fazer calmamente suas abluções (ritual de limpeza corporal obrigatório antes das orações), quanto para tirar dúvidas com o Imam a respeito da religião.

Geralmente, ao chegarem à mesquita, e após cumprimentarem-se ("assalam aleikum" - "A paz esteja com você"), os membros da comunidade, tanto homens quanto mulheres, se encaminham para o banheiro para fazer a ablução ou sentam-se no carpete que cobre o chão da SBMRJ. Enquanto esperavam pelo Imam, que muitas vezes estava resolvendo questões administrativas da mesquita, alguns conversavam entre si e outros, notavelmente os que tinham domínio da língua árabe, liam exemplares do Alcorão que estavam disponíveis nas prateleiras.

A prática da ablução, por ser parte do ritual das orações, é frequentemente ensinada aos recém-convertidos pelos membros da comunidade, especialmente pelos nascidos muçulmanos que costumam dar aulas de religião na SBMRJ. O ensino dos procedimentos que devem ser seguidos na ablução pode ser feito tanto individualmente quanto em grupos, dependendo da ocasião. Certa vez, antes de uma aula de religião na SBMRJ, presenciei a diretora do departamento feminino, nascida muçulmana, ensinando as etapas da ablução a um grupo de três mulheres brasileiras recém-convertidas, que anotavam em seus cadernos o que lhes era dito.

Também presenciei o ensino da ablução a um menino - de cerca de 13 anos - , nascido muçulmano, orientado pela mesma diretora durante um curso, ministrado por ela e direcionado aos membros mais jovens da comunidade, sobre os fundamentos da religião. Após explicar ao menino as razões religiosas da ablução, o levou até o banheiro para mostrar-lhe como proceder corretamente, sendo que o menino dizia que "já sabia mais ou menos como fazer a ablução, porque via seus pais fazendo".

No primeiro exemplo, para as convertidas, aprender os modos corretos da ablução, antes de ser um saber prático, se constituiu como um saber discursivo 
objetificado, em que os procedimentos eram anotados e repetidos conscientemente, para se evitar possíveis esquecimentos e distorções a respeito da prática (Whitehouse 2000:100-112). Já no caso do menino, evidenciou-se um saber técnico corporificado da ablução através da imitação. O que reforça que, enquanto para as convertidas aprender a fazer ablução era uma novidade, para o menino nascido em família muçulmana, o costume lhe era familiar e o aprendizado na mesquita era entendido mais como um aperfeiçoamento desse hábito do que como um novo conhecimento.

A ablução deve ser repetida antes de cada oração caso o muçulmano tenha praticado alguma ação que possa ter feito com que a sua primeira ablução perdesse a validade. Esse ritual de purificação parcial do corpo, que implica lavar as mãos, o rosto e os pés de acordo com uma certa ordem e número de vezes, foi codificado pedagogicamente em procedimentos que podem ser explicados e ensinados. A importância dada ao ensino da ablução na SBMRJ se deve sobretudo ao fato de se tratar de uma comunidade voltada para a divulgação do Islã, tendo convertidos como a maior parte de seus membros. Além da transmissão oral e prática da ablução, como nos exemplos mencionados acima, também na página eletrônica da instituição pode ser encontrado um texto explicativo que diz "passo-a-passo" como fazê-la.

O ritual da oração começa com o adhan (chamada da oração). Em países majoritariamente muçulmanos há pessoas específicas para a realização dessa tarefa, mas no caso da SBMRJ essa função é realizada por membros (homens) da comunidade que tenham um bom domínio do idioma árabe. A chamada é feita em tom de recitação e é pronunciada em árabe, não sendo traduzida ou acompanhada pelos demais membros: "Alláhu Akbar (4v), ach hádo an lá illahá illalah (2v), ua ach hádo anna Mohammadan Rassullullah (2v), haia alas salat (2 v) haia alalfalah (2 v), Alláhu Akbar (2v), la iláha illaláh" ("Deus é o maior (4v)/ Testemunho que não há outra divindade além de Deus (2v)/ Testemunho que Muhammad é o mensageiro de Deus (2v)/ Vinde para a oração (2v)/ Vinde para a salvação (2v)/ Deus é o maior (2v)/ Não há outra divindade além de Deus").

No momento em que a chamada da oração é feita, quem a faz deve ficar de pé, direcionado para o mihrab, que fica posicionado em direção a Meca. No caso da SBMRJ, o mihrab é o próprio minbar, púlpito a partir do qual o Imam profere os sermões. Todos os demais membros da comunidade devem ficar sentados (no chão da mesquita) e em silêncio enquanto a chamada é feita. Ao seu término, todos ficam de pé, também direcionados ao mihrab, organizados em fileiras alinhadas, com as cabeças baixas. O Imam, neste caso aquele que vai liderar a oração, se posiciona à frente dos demais membros da comunidade e, de costas para eles, pronuncia "Allahu Akbar" ("Deus é o maior"), levantando as mãos na altura das orelhas. Os demais participantes também fazem o mesmo gesto e, em seguida, abaixam as mãos, colocando-as sobre o abdômen - a mão 
direita deve se sobrepor à mão esquerda, segurando o antebraço esquerdo. Então, o Imam começa a recitar a surata (capítulo) de abertura do Alcorão AlFatiha. Depois, o Imam pronuncia a segunda surata (que ele próprio pode escolher).

Ao término dos pronunciamentos das suratas, feitos somente pelo Imam em um tom audível por todos, os primeiros movimentos corporais (1 ${ }^{a}$ genuflexão, em que são feitas inclinações com o corpo para frente apoiando as mãos nos joelhos, depois do que as pessoas devem se ajoelhar e fazer as prostrações) são feitos por todos os muçulmanos seguidos por alguns pronunciamentos, louvores a Deus em árabe. Em seguida, o Imam, em pé, recita novamente a primeira surata e mais outra surata qualquer (pode repetir a que já foi feita anteriormente), que são ouvidas pelos muçulmanos, que também ficam em pé neste momento. Ao término do pronunciamento das suratas, os movimentos corporais são repetidos (2 a genuflexão). No final, de joelhos, os muçulmanos devem virar a cabeça para a direita e dizer: "Salam Aleikum Rahmatullah" ("A paz e a misericórdia de Deus estejam convosco") e depois devem fazer o mesmo para o lado esquerdo. Alguns muçulmanos, ao terminar o ritual, rapidamente se levantam e deixam a mesquita, enquanto outros permanecem fazendo mais orações individuais ou conversando.

Em uma das orações de sexta-feira a que assisti, os nascidos muçulmanos que geralmente pronunciam a chamada da oração na SBMRJ não estavam presentes. Então, Imam Omar perguntou aos membros da comunidade quem, dentre eles, teria condições de fazê-lo. Houve um silêncio e trocas de olhares entre os indivíduos da comunidade. Imam Omar sorriu e fez a pergunta novamente. Um muçulmano brasileiro convertido e que fizera o curso de religião oferecido na SBMRJ na mesma turma que eu (um dos alunos mais aplicados no estudo da língua árabe), se levantou e pronunciou a chamada. Os demais membros da comunidade ficaram em silêncio e alguns olhavam atentamente para o rapaz. Através da minha frequência às orações, embora naquele momento não tivesse fluência no idioma, adquiri certa noção em relação ao ritmo em que as fórmulas rituais são recitadas e percebi que na chamada que o rapaz estava fazendo havia problemas com a pronúncia. Isso obviamente foi notado pelos demais membros da comunidade. Um homem árabe, por volta dos 65 anos, de origem síria e nascido muçulmano, que estava sentado próximo a mim na mesquita, esboçou expressões faciais de desagrado em relação ao que estava ouvindo. Quando o rapaz terminou, Imam Omar lhe disse educadamente e em tom de voz baixo que a chamada que ele fizera estava com problemas na pronúncia. O rapaz não respondeu nada e, em seguida, Imam Omar perguntou quem mais poderia fazer a chamada. Um membro nascido muçulmano e descendente de árabes se levantou e fez. Após isso, o ritual prosseguiu. Foi a primeira vez, nas dezenas de orações coletivas que assisti na SBMRJ, que um muçulmano convertido fez a chamada da oração.

Esse episódio demonstra, mais uma vez, como as articulações entre 
conhecimento religioso e domínio da língua árabe estão presentes no cotidiano da mesquita, servindo, também, como uma forma de diferenciação simbólica entre os membros da comunidade (árabes versus não árabes). Imam Omar, em função da posição de poder que ocupa na SBMRJ, pôde intervir naquela prática, corrigindo-a publicamente e autorizando sua repetição.

As suratas do Alcorão que são recitadas nas orações rituais dependem do conhecimento textual que os agentes religiosos têm do livro sagrado, bem como de sua capacidade de memorizá-lo. No Islã, a memorização ${ }^{13}$ do Alcorão, em árabe, é considerada como uma das formas mais recomendadas de adoração a Deus, e quem o tem memorizado contará com méritos a seu favor no dia do juízo final. Nesse sentido, o Imam que lidera uma oração comunitária, como as que ocorrem nas sextas-feiras, por exemplo, deve ser alguém que possua ao menos uma quantidade razoável de suratas memorizadas e que tenha boa fluência na língua árabe.

Há regras fixas estabelecidas no ritual da oração. Além dos louvores que são pronunciados no final, a oração é composta pela recitação de três suratas ao todo, sendo que a surata de abertura (Al-Fatiha) é obrigatória em todas as orações e é repetida duas vezes em cada. As outras duas suratas são escolhidas por quem está liderando a oração e geralmente não são longas. As pronúncias das suratas são intercaladas com súplicas e posturas corporais (genuflexões).

Na SBMRJ os muçulmanos convertidos são socializados no ritual de oração de diferentes maneiras. $O$ primeiro contato com a língua árabe geralmente ocorre no rito de conversão, em que eles pronunciam publicamente a declaração de fé (shahada), em árabe ("la ilah ila Allah Muhammad Rasul Allah" - que significa o testemunho "que não há outro deus senão Deus e que o Profeta Muhammad é Seu mensageiro"). Para tanto, alguns muçulmanos convertidos me informaram que escreveram a transliteração da shahada e a memorizaram. Durante meu trabalho de campo, assisti a três conversões e em todas elas o Imam pronunciava a shahada pausadamente e a pessoa repetia em seguida.

Já com relação às orações é indicado que todos os muçulmanos estudem a língua árabe e memorizem o Alcorão. Como a SBMRJ está voltada para atividades de divulgação e socialização dos muçulmanos convertidos na doutrina e nas práticas islâmicas, há cursos de memorização do Alcorão que são oferecidos e também CDs contendo suratas do Alcorão, que são disponibilizados para auxiliar na memorização. Alguns membros convertidos da comunidade me disseram que nas orações que fazem em casa geralmente leem as suratas, muitas vezes transliteradas, por não terem-nas memorizadas e nem conseguirem lê-las em árabe. Embora a leitura do Alcorão nas orações seja aconselhada para quem está começando na religião, é recomendável que a memorização seja feita como prova de empenho religioso.

Um dia, após a oração de sexta-feira, perguntei a Ana, uma muçulmana 
brasileira, 37 anos, desempregada, divorciada e convertida há dois anos, se ela entendia o que era pronunciado nas orações. Ela me respondeu que entendia a surata de abertura, mas que não tinha conhecimento de muitas outras suratas que eram pronunciadas nas orações. Então, perguntei como ela fazia para rezar na mesquita se ela não sabia o que estava sendo dito. Ela me respondeu que o Imam, ao pronunciar as suratas, o estava fazendo por todos os presentes e que ela, nesses momentos, fazia suas intenções, pedidos e agradecimentos individuais a Deus.

Em conversa com outros membros convertidos da comunidade, homens e mulheres, obtive informações parecidas. Um estudante universitário convertido havia dois meses me disse que obteve um livro com as suratas transliteradas e traduzidas para o português e que o usava para as orações feitas em casa. Outra mulher, convertida havia um ano, me disse que também tinha o referido livro e que anotava uma ou duas suratas em um caderno todos os dias, tanto para praticar a memorização através das cópias escritas, quanto para realizar as orações em seu ambiente de trabalho.

Já os árabes (ou descendentes) nascidos muçulmanos me informavam que já tinham algumas suratas memorizadas, pois já faziam orações há muitos anos, e que liam o Corão em língua árabe mais no sentido de obter conhecimento a respeito do que estava escrito do que com a preocupação de memorizá-lo para fazer suas preces.

Dessa forma, fica evidenciado que as orações assumem diferentes sentidos para os participantes de acordo com o grau de conhecimento textual (em árabe) da religião que possuem, uma vez que os nascidos muçulmanos, quando sabem as suratas que estão sendo pronunciadas, podem repeti-las individualmente para si, pois só o Imam fala durante o ritual das orações. Já os convertidos faziam suas preces mentalmente em língua portuguesa, mas utilizando alguns vocábulos em árabe como Allah (tradução para Deus na língua árabe) em substituição de Deus (português). No entanto, como assinalou Mauss (1909), mesmo nas orações individuais, não há uma possibilidade criativa ilimitada dada aos agentes religiosos, uma vez que a tradição religiosa cria um vocabulário oral (e mental) específico na comunicação com o sagrado.

Outro aspecto altamente valorizado nas orações é a postura corporal dos muçulmanos. Durante o ritual da oração, o muçulmano deve realizar alguns movimentos corporais como, por exemplo, inclinar o corpo para frente apoiando as mãos no joelho, ajoelhar e prostrar-se com as mãos e a testa apoiadas no chão. Tais técnicas corporais (Mauss 1974:211) são ensinadas na SBMRJ, principalmente para os muçulmanos convertidos, de duas formas: na primeira, há o ensino via transmissão oral, em que o muçulmano que está ensinando, notavelmente os professores de religião, narra os procedimentos corporais que devem ser feitos na oração; na segunda, o instrutor demonstra-os na prática para aqueles que estão 
aprendendo, indicando exatamente como determinadas partes do corpo devem ser posicionadas.

Em um sábado, dia das aulas de religião na mesquita, presenciei o ensinamento das técnicas corporais empregadas nas orações para um pequeno grupo de muçulmanas brasileiras, com idades variadas (entre 30 e 40 anos) e recém-convertidas, minhas colegas no referido curso. Nassíba, diretora do departamento feminino da instituição, era quem estava orientando as outras mulheres, e thes dizia que a postura corporal era muito importante para que as orações tivessem validade. Ressaltou que todas as normas deveriam ser seguidas porque foram estabelecidas pelo profeta Muhammad. Após explicar tais razões, ela começou a fazer os movimentos, para que as mulheres pudessem "ver" e "fazer" corretamente. Depois, as alunas realizaram os mesmos movimentos, com a supervisão de Nassíba, que lhes indicava o que estava errado em suas posturas e como corrigir.

A segunda forma de transmissão de conhecimento a respeito de como se fazer as orações é através do ensino diretamente prático, via ritual. O ritual em si é um processo disciplinar que envolve duas funções: a observação contínua e a correção das práticas (Asad 1993:161). Em outras palavras, pode-se dizer que um muçulmano também aprende a performance corporal que ele deve desempenhar nas orações através da observação e da imitação que ele faz dos outros muçulmanos durante a cerimônia coletiva. Isso é possível porque as técnicas corporais empregadas no ritual da oração são estabelecidas e regulamentadas pela tradição religiosa (Mauss [1909]:137), tendo funções normativas, permitindo, portanto, que o processo de aprendizado seja consciente e envolva tanto mecanismos cognitivos quanto corporais na sua execução.

Assim sendo, percebe-se que no rito das orações diferentes formas de saberes são acionadas, como, por exemplo, o saber textual, a partir da memorização e da recitação do Alcorão, e o saber prático, a partir do emprego de técnicas corporais na performance ritual. A aquisição de ambos os saberes envolve práticas disciplinares que visam a criar disposições nos agentes religiosos, as quais são corporificadas como parte de suas identidades religiosas (Asad 1993:125).

Como a SBMRJ está voltada para a divulgação do Islã e para a conversão, os rituais também estão organizados em uma moldura pedagógica que busca a socialização dos muçulmanos convertidos através da codificação discursiva do ritual prático da oração, como pode ser evidenciado no texto explicativo sobre "Como fazer a oração" disponível na página eletrônica da instituição. Alguns muçulmanos convertidos me disseram que usam esse texto por ser um bom meio de aprendizado, pois eles podem lê-lo e seguir as orientações nos momentos em que fazem suas orações em esferas privadas (casas e locais de trabalho). No entanto, os mesmos interlocutores afirmaram que o aprendizado maior é conseguido pelo ensinamento prático obtido através dos "professores" de religião e nos próprios rituais que ocorrem na mesquita. 


\section{Considerações finais}

Na comunidade sunita do Rio de Janeiro, os princípios doutrinais islâmicos são apresentados de forma objetificada (Eickelman \& Piscatori 1996:38), isto é, como princípios livres de quaisquer influências culturais e sociais. Essa concepção universalista dos valores islâmicos, sustentada principalmente pelos líderes da SBMRJ, confere uma orientação missionária à instituição, no sentido de divulgar o Islã na sociedade brasileira, afirmando-o como uma alternativa no campo religioso local.

Nesse processo, as formas de divulgação do Islã e a integração dos convertidos na instituição são feitas em um quadro disciplinar que organiza a transmissão de conhecimento religioso entre seus membros, tanto através de atividades pedagógicas e discursivas - como as aulas de religião e os textos localmente produzidos, por exemplo - quanto via ritual, como ocorre com as orações de sexta-feira, que se constituem no principal momento de congregação dos membros da SBMRJ.

O material etnográfico apresentado neste artigo abordou especificamente a oração de sexta-feira, tal como praticada pelos muçulmanos do Rio de Janeiro, e os diferentes efeitos que esse ritual produz nas identidades religiosas dos seus praticantes. Através dele, os muçulmanos não só renovam seus votos individuais de submissão a Deus e de pertencimento ao Islã, como também afirmam publicamente quem são, para verem e serem vistos como membros da comunidade religiosa local (SBMRJ) e global (ummah).

Os efeitos disciplinares do ritual da oração na construção das identidades religiosas dos diferentes agentes sociais estão conectados, tal como argumentado por Harvey Whitehouse (2000), às formas de codificação (doutrinal ou imagística) que organizam a transmissão de conhecimento nas tradições religiosas. No caso do Islã, como uma tradição discursiva/doutrinal (Asad 1986; Whitehouse 2000), as ações rituais têm por referência os textos corânicos que são compartilhados pela ampla comunidade de fiéis e o formato rotinizado e repetitivo de sua prática reproduz e estabiliza as ideias religiosas.

Uma tradição religiosa codificada doutrinalmente, no entanto, para ser duradoura, necessita dominar as formas pelas quais seus valores normativos são transmitidos e, para tanto, cria os especialistas religiosos - aqueles que sabem o texto e são autorizados para controlar seus significados (Asad 1986). Nesse sentido, as diferentes transações de conhecimento que circulam numa dada comunidade religiosa e os meios nos quais tal conhecimento é transmitido dependem de como ele é gerenciado contextualmente, na interação social (Barth 2000).

$\mathrm{Na}$ conjuntura aqui discutida, a oração de sexta-feira, mais do que um ritual obrigatório, configura-se um campo (Bourdieu 2001) em que disputas simbólicas em torno do conhecimento religioso islâmico e de sua "correta" 
performance ritual são travadas entre os muçulmanos do Rio de Janeiro. Nessa contenda, não só questões específicas relativas à doutrina são mobilizadas, mas também elementos como o pertencimento étnico, o domínio da língua árabe, e as relações de poder estabelecidas entre os membros da comunidade, por exemplo, são colocados em evidência.

Um importante ponto a ser elucidado, então, é o papel da língua árabe na sociedade sunita do Rio de Janeiro. Durante meu trabalho de campo, vários dos meus interlocutores, tanto nascidos muçulmanos quanto convertidos, colocaram o domínio desse idioma como um elemento-chave para a aquisição de conhecimento religioso (através da leitura do Corão) e para a prática correta da oração, uma vez que precisam acionar a memória para recitarem as suratas. No entanto, apesar de a língua árabe ser localmente valorizada mais como um elemento religioso, "divino", do que como um elemento étnico, a demonstração pública desse saber por parte dos árabes e de seus descendentes produz efeitos práticos na construção das identidades religiosas (nascidos muçulmanos ou convertidos) e das fronteiras étnicas que são delineadas entre os membros da comunidade.

Os árabes e seus descendentes nascidos muçulmanos, por exemplo, ao menos teoricamente, possuem o domínio da língua árabe e, logo, podem ter acesso direto aos textos sagrados da tradição sunita, além de serem capazes de pronunciar e entender as fórmulas rituais que são proferidas durante as orações. Por sua vez, os brasileiros convertidos com os quais tive contato procuravam dar coerência às suas novas crenças religiosas incorporando-as ao seu cotidiano, de modo algumas vezes mais incisivo do que faziam os nascidos muçulmanos, como na frequência assídua aos rituais da oração, no aprendizado discursivo e prático das posturas corporais a serem executadas nesse momento, no empenho em memorizar algumas suratas do Alcorão - mesmo que através de transliterações - e nas demais atividades oferecidas pela SBMRJ.

A mobilização da etnicidade árabe na SBMRJ está vinculada a uma esfera de saber religioso herdada culturalmente pelos árabes e seus descendentes nascidos muçulmanos, que faltaria aos muçulmanos convertidos e sem origem árabe. Nesse sentido, a identidade étnica (árabe) dos membros da SBMRJ é percebida mais como um instrumento valorativo de conhecimento religioso do que um elemento definidor da identidade muçulmana, sendo também considerada na delimitação das fronteiras simbólicas que classificam os membros da comunidade, principalmente com relação às posições de poder estabelecidas entre eles.

Assim, tal como esta análise do ritual da oração procurou indicar, as identidades religiosas dos membros da comunidade sunita do Rio de Janeiro são construídas tendo por base as diferentes inserções e posições de poder que eles ocupam no interior da comunidade, o que demonstra as múltiplas formas pelas quais os processos de transmissão e de incorporação da doutrina e das práticas islâmicas que circulam na SBMRJ são vivenciados pelos agentes religiosos. 


\section{Referências Bibliográficas}

ASAD, Talal. (1986), The Idea of an Anthropology of Islam. Washington: Georgetown University. .(1993), Genealogies of Religion. Baltimore: John Hopkins University Press.

BARTH, Fredrik. (2000), O Guru, o Iniciador e Outras Variações Antropológicas. Rio de Janeiro: Contra Capa Livraria.

BOURDIEU, Pierre. (s.d.), "Esboço de uma teoria da prática". In: R. Ortiz. Pierre Bourdieu. São Paulo: Ática, pp. 46-81. (Coleção Grandes Cientistas Sociais).

. (1997), Outline of a Theory of Practice. Cambridge: Cambridge University Press. (2001), O Poder Simbólico. Rio de Janeiro: BCD União Editoras S. A.

CHAGAS, Gisele Fonseca. (2006), Identidade, Conhecimento e Poder: a comunidade muçulmana sunita do Rio de Janeiro. Rio de Janeiro: Dissertação de Mestrado em Antropologia, UFF.

CHARTIER, Roger. (1998), A Aventura do Livro: do leitor ao navegador. São Paulo: UNESP/Imprensa Oficial do Estado.

DEEB, Lara. (2006), An Enchanted Modern: gender and public piety in Shi'i Lebanon. Princeton: Princeton University Press.

EICKELMAN, Dale. (1985), Knowledge and Power in Morocco. Princeton: Princeton University Press. \& PISCATORI, James. (1996), Muslim Politics. Princeton: Princeton University

Press.

FERREIRA, Francirosy C. Barbosa. (2007), Entre Arabescos, Luas e Tâmaras: performances islâmicas em São Paulo. São Paulo: Tese de Doutorado em Antropologia, USP.

GOODY, Jack. (1987), A Lógica da Escrita e a Organização da Sociedade. Lisboa: Edições 70.

HENKEL, Heiko. (2005), "Between belief and unbelief lies the performance of salat: meaning and efficacy of a Muslim ritual". Journal of Royal Anthropological Institute, no 11: 487-507.

MAHMOOD, Saba. (2005), Politics of Piety: the islamic revival and the feminist subject. Princeton: Princeton University Press.

MAUSS, Marcel. ([1909] 1979), “A prece”. In: R. C. de Oliveira (org.). Marcel Mauss. Rio de Janeiro: Editora Ática, pp.103-146. (Coleção Grandes Cientistas Sociais).

(1909), La Prière. Disponível em: http://www.uqac.uquebec.ca/ zone30Classiques_des_sciences_sociales/index.html. Acesso em: 04 abr. 2009.

(1974), "Noção de técnica corporal". In: Ensaio sobre a Dádiva. Sociologia e Antropologia. São Paulo: EPU/EDUSP, vol II, pp.212-218.

MONTENEGRO, Maria Silvia. (2000), Dilemas Identitários do Islam no Brasil - A comunidade muçulmana sunita do Rio de Janeiro. Rio de Janeiro: Tese de Doutorado em Antropologia, IFCS/ UFRJ.

PINTO, Paulo Gabriel Hilu R. (2004a), "The limits of the public sufism and the religious debate in Syria”. In: A. Salvatore \& D. Eickelman (eds.). Public Islam and the common good. Leiden: Brill. . (2004b), "Islamismo". In: F.C.T. Silva (org.). Dicionário de Guerras e Revoluções no Século XX. Rio de Janeiro: Campus.

. (2005a), "Ritual, etnicidade e identidade religiosa nas comunidades muçulmanas no Brasil". Revista USP, no 67: 228-250.

. (2005b), "Ritual, experiência mística e lei islâmica nas comunidades sufis de Alepo,

Síria”. Anuário Antropológico, 2004: 51-94. Rio de Janeiro: Tempo Brasileiro.

REIS, João José. (2003), Rebelião escrava no Brasil: a história do levante dos malês em 1835. São Paulo: Companhia das Letras.

WHITEHOUSE, Harvey. (2000), Arguments and Icons. Oxford: Oxford University Press. 


\section{Notas}

1 Este artigo é uma análise condensada do capítulo 4 de minha dissertação de Mestrado, defendida em 2006 com o título "Identidade, conhecimento e poder na comunidade muçulmana sunita do Rio de Janeiro", no Programa de Pós-Graduação em Antropologia da Universidade Federal Fluminense. Os dados aqui apresentados foram coletados por mim no meu trabalho de campo durante o ano de 2005 e janeiro de 2006, na referida comunidade, na qual eu participei das atividades e rituais praticados por eles, além de ter visitado seus membros em suas casas e locais de trabalho. Neste artigo, os nomes dos meus informantes são fictícios, para preservar-lhes a privacidade.

2 O Islã se divide em duas comunidades sectárias: o Sunismo, que baseia suas doutrinas e rituais no Alcorão e nas tradições relativas à vida do Profeta (Sunna), com a interpretação e a aplicação das doutrinas religiosas sendo administradas por especialistas religiosos; e o Xiismo que baseia o seu sistema doutrinário e ritual no texto corânico e na mensagem esotérica dos Imams (descendentes de Maomé pela linha de Ali e Hussein), sendo os detentores das funções jurídicas e religiosas aqueles que tem, na hierarquia religiosa, o título de ayatollah ou marja' (fonte de inspiração) - (Pinto 2004b:484). Como horizonte normativo que une esta diversidade, podem ser destacados os cinco pilares do Islã (o testemunho, a oração, a doação de esmolas, o jejum e a peregrinação), além dos textos sagrados. A tradição xiita também é internamente fragmentada: há o grupo majoritário, que é conhecido como duodecimano ou jafa'ri, que cultua os doze imams que sucederam o Profeta, além dos Zeyditas e Ismaelitas, que romperam com os duodecimanos a partir do quarto e do sexto imams, respectivamente, e criaram linhas de descendência próprias, adotando regras diferentes. Também existem os alauítas, os druzos e outros pequenos grupos que têm vínculos doutrinais e históricos com o xiismo. E o Sufismo, vertente mística do Islã, sendo praticado principalmente por sunitas.

3 Os rituais xiitas e sufi, por exemplo, estão combinados em diversos níveis com os modos de codificação religiosa classificados por Harvey Whitehouse em "doutrinal" e "imagístico". Para uma análise da construção das identidades sufi, ver Pinto (2004a).

4 Sigo a definição de habitus dada por Pierre Bourdieu: “(...) um sistema de disposições duráveis e transponíveis que, integrando todas as experiências passadas, funciona a cada momento como uma matriz de percepções, de apropriações e ações" (Ortiz s. d.).

5 No período de meu trabalho de campo, a comunidade estava empenhada na construção de uma mesquita maior, em estilo arquitetônico islâmico. No ano de 2008, as orações já estavam sendo praticadas nesse novo centro ritual, localizado no bairro da Tijuca, na cidade do Rio de Janeiro. Tal bairro apresenta uma pluralidade de centros religiosos das mais diferentes religiões.

6 No período de meu trabalho de campo eram 190 associados formais.

7 Conversão aqui é entendida como aceitação intelectual e emocional de uma outra doutrina religiosa por parte de um indivíduo, diferente daquela em que ele teria sido inicialmente socializado. No caso deste artigo, brasileiros anteriormente cristãos que se converteram ao Islã. Utilizo a categoria "convertido(a)" para designar os brasileiros muçulmanos, sem ascendência árabe, com os quais interagi durante meu trabalho de campo, pois era com essa categoria que eles se identificavam. Para uma outra análise, que utiliza a categoria "revertidos" para classificar brasileiros que adotaram o Islã em São Paulo, ver Ferreira (2007).

8 Durante meu trabalho de campo tive pouco contato com a comunidade africana que frequentava as orações de sexta-feira, por isso não me foi possível esboçar-lhe um perfil sociológico. Quanto ao grupo de "árabes" ao qual me refiro, é importante ressaltar que seus integrantes pertencem a diferentes nacionalidades, tais como sírios, libaneses, palestinos etc., mas que no contexto local dessa comunidade sunita compartilham a ideia de que árabe é aquele que possui uma língua em comum, independente do local geográfico de origem. Para uma maior discussão sobre o assunto, ver Chagas (2006).

9 As transliterações e traduções das palavras em árabe que aparecem ao longo desta dissertação foram 
copiadas por mim de textos sobre Islã produzidos pelos membros da SBMRJ, para manter os significados que lhes são localmente conferidos.

${ }^{10}$ Este dito pode ser encontrado na coleção de hadiths compiladas por Bukhari (Paulo Gabriel Hilu da Rocha Pinto, comunicação oral, 2009). Muhammad Ibn Ismail al-Bukhari (século IX) é considerado pela maioria dos muçulmanos como um dos mais importantes compiladores das hadiths atribuídas ao Profeta Muhammad.

${ }^{11}$ Os nomes aqui citados são fictícios, para preservar a privacidade dos meus interlocutores. A atribuição de nomes aos interlocutores procurou seguir uma lógica de acordo com os seus nomes reais. Por exemplo, grande parte deles (brasileiros sem ascendência árabe e convertidos ao Islã) manteve seus nomes de origem, não adotando nomes árabes com inspiração religiosa. Então, atribuí a eles nomes comuns empregados no contexto cultural brasileiro. A mesma lógica se aplica para os interlocutores árabes (ou descendentes) cujos nomes de origem são em árabe. Embora no momento de minha pesquisa houvesse um pequeno número de convertidos que adotou um outro nome em árabe, o fato da maioria deles ter optado por permanecer com seus nomes de origem reflete, de certa maneira, as tensões entre identidade étnica (árabe) e identidade religiosa (muçulmana) que existem na comunidade. Uma vez que o discurso oficial da comunidade é o do Islã como uma religião universal, que pode ser vivenciada em qualquer espaço e tempo, desvinculada de qualquer etnicidade, a opção dos convertidos por permanecerem com seus nomes de origem não árabe é parte desse processo, inscrevendo, então, o Islã como uma alternativa no campo religioso brasileiro. $\mathrm{O}$ Imam local é considerado como aquele que mais possui conhecimento religioso dentre os membros da comunidade, fator que legitima sua posição de autoridade religiosa. Nascido no Sudão e sem uma formação religiosa tradicional, Imam Omar chegou ao Brasil no início da década de 1990, local em que construiu sua carreira de líder religioso. Sua configuração identitária como árabe e africano, aliado à construção de sua experiência como líder religioso no Brasil, o ajudaram a estabelecer sua autoridade religiosa entre os três maiores grupos étnicos que compõem a comunidade sunita do Rio de Janeiro. Durante meu trabalho de campo, questões relativas à definição de pertencimento a uma das "escolas" de jurisprudência islâmica - que no Sunismo são quatro: hanafi, hanbali, maleki e shafi'i - se mostraram irrelevantes. A invocação e o pertencimento a uma dessas "escolas" são contextualmente produzidos. Para uma análise dos processos pelos quais sistemas jurídicos transnacionais, como a lei islâmica, por exemplo, são contextualmente articulados e inscritos nas práticas sociais, ver Pinto (2005b).

Recebido em abril de 2009 Aprovado em novembro de 2009

Gisele Fonseca Chagas (giselerpe@gmail.com)

Doutoranda em Antropologia do Programa de Pós-Graduação em Antropologia da Universidade Federal Fluminense e pesquisadora do Núcleo de Estudos do Oriente Médio (NEOM/UFF). 


\section{Resumo:}

Este artigo focaliza o papel que o ritual da oração coletiva de sexta-feira, praticado pelos muçulmanos sunitas do Rio de Janeiro, tem na construção de suas identidades religiosas. Considerando que a ideia de obtenção de conhecimento religioso (textos doutrinais e práticas rituais) da tradição sunita é central nos discursos dos membros dessa comunidade, as várias formas através das quais esse conhecimento é posto em circulação, apropriado e mobilizado via ritual da oração criam distinções cumulativas, que estabelecem diferentes fronteiras, poderes e identidades para os membros da comunidade sunita do Rio de Janeiro, de acordo com suas etnicidades e inserções no Islã (nascidos muçulmanos ou convertidos).

Palavras-chave: Islã, etnicidade, conhecimento religioso, oração.

\section{Abstract:}

This paper focus on the role of the Friday's prayer ritual practiced by the Sunni Muslim of Rio de Janeiro has in the construction of their religious identities. Considering that the idea of obtaining religious knowledge of the Sunni Tradition plays an important role in the community's members discourses, the various forms that the knowledge is circulated, appropriated and mobilized in the prayer's ritual create cumulative differences that give different positions, powers and identity to the members of the Sunni community of Rio de Janeiro, according to their ethnicities and ways of becoming Muslim (having a Muslim heritage or being Converted).

Keywords: Islam, ethnicity, religious knowledge, prayer. 